\title{
Structural relaxation of $\mathrm{PbO}-\mathrm{WO}_{3}-\mathrm{P}_{2} \mathrm{O}_{5}$ glasses
}

\author{
$\underline{\text { M. Chromčíkováa }}^{1,2}$, B. Hruška ${ }^{3}$, M. Liška ${ }^{1,2}$ \\ ${ }^{1}$ VILA - Joined Glass Centre of the IIC SAS, TnUAD, FChPT STU, Študentská 2, \\ SK-911 50 Trenčín, Slovakia \\ (E-mail: maria.chromcikova@tnuni.sk) \\ ${ }^{2}$ VILA, FunGlass, A. Dubcek University of Trenčín, Študentská 2, SK-911 50 Trenčín, Slovakia \\ ${ }^{3}$ Central Laboratories, FunGlass, Alexander Dubček University of Trenčín, Študentská 2 , \\ SK-911 50 Trenčín, Slovakia
}

\begin{abstract}
The structural relaxation of three compositional series of $\mathrm{PbO}-\mathrm{WO}_{3}-\mathrm{P}_{2} \mathrm{O}_{5}$ glasses with composition $(0.5-x / 2) \mathrm{PbO} \cdot x \mathrm{WO}_{3} \cdot(0.5-x / 2) \mathrm{P}_{2} \mathrm{O}_{5}, \quad x=0,0.1, \quad 0.2, \quad 0.3,0.4, \quad 0.5$; $0.5 \mathrm{PbO} \cdot x \mathrm{WO}_{3} \cdot(0.5-x) \mathrm{P}_{2} \mathrm{O}_{5}, x=0,0.1,0.2,0.3$; and $(0.5-x) \mathrm{PbO} \cdot x \mathrm{WO}_{3} \cdot 0.5 \mathrm{P}_{2} \mathrm{O}_{5}, x=0$, $0.1,0.2,0.3,0.4,0.5$ was studied by thermomechanical analysis $[1,2]$. The relaxation was described using a mathematical model based on the stretched exponential relaxation function with relaxation time proportional to actual viscosity. The viscosity dependence on thermodynamic temperature and fictive temperature was expressed by Mazurin's approximation $[3,4,5]$. The relaxation parameters dependence on the glass composition was studied. It was found that the modulus is increasing with increasing amount of $\mathrm{WO}_{3}$ in all glasses. On the contrary, the width of the spectrum of relaxation times is decreasing with increasing amount of $\mathrm{WO}_{3}$ in all studied glasses.
\end{abstract}

Keywords: Phosphate glasses, Structural relaxation, Viscosity, Glass transition.

\section{Acknowledgment:}

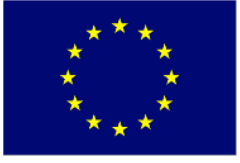

This paper is a part of dissemination activities of project FunGlass.

This project has received funding from the European Union's Horizon 2020 research and innovation programme under grant agreement No 739566.

This work was supported by The Slovak Grant Agency for Science under grant No. VEGA 2/0088/16, VEGA 1/0064/18.

\section{References:}

[1] Koudelka L, Lissová M, Rosslerová I, Mošner P, Černošek Z, Liška M, Montagne L, Delevoye L, Delevoye L. Structure and properties of lead tungstate phosphate glasses. Phys Chem Glasses: Eur J Glass Sci Technol B. 2012;53:86-92.

[2] Mošner P, Vosejpková K, Koudelka L, Montagne L, Revel B. Structure and properties of glasses in ZnO-P2O5-TeO2 system. J Non-Cryst Solids. 2011;357:2648-52.

[3] Mazurin OV. Steklovanie Nauka. Leningrad; 1986. p. 158.

[4] Tool AQ. Relation between inelastic deformability and thermal expansion of glass in its annealing range. J Am Ceram Soc. 1946;29:240-53.

[5] Liška M, Štubňa I, Antalík J, Perichta P. Structural relaxation with viscous flow followed by thermodilatometry. Ceramics-Silikáty. 1996;40:15-9. 